\title{
Technology and Mediated Instruction
}

\section{ISSUE HIGHLIGHTS:}

NALLD JOURNAL INDEX VOLS. 1-13

James Eiseman, Issue Editor

Journal of the National Association of Learning Laboratory Directors Volume 14, Number $3 / 4$

Spring/Summer 1980 
NALLD JOURNAL:

TECHNOLOGY AND MEDIATED INSTRUCTION

NALLD JOURNAL: TECHNOLOGY AND MEDIATED INSTRUCTION (ISSN 0027-5905) is currently published three times a year (Fall, Winter, and Spring/Summer) by the National Association of Learning Laboratory Directors (NALLD). Membership in the Association is open to anyone associated with or interested in furthering the effective use of media in all areas of instruction. The membership year begins on October 1st and includes a personal subscription to the JOURNAL.

Opinions expressed in signed articles are those of the authors and not of NALLD. Although NALLD attempts to screen advertising for integrity, all advertising remains the responsibility of the advertiser. Neither opinions nor advertising carry NALLD approval unless adopted by the NALLD Executive Board. The NALLD JOURNAL is indexed in the CURRENT INDEX OF JOURNALS IN EDUCATION and is cited in LANGUAGE AND LANGUAGE BEHAVIORAL ABSTRACTS.

Manuscripts submitted for review should be double-spaced and sent in triplicate to NALLD JOURNAL, A \& S Learning Lab., Bingham Humanities 16, University of Louisville, Louisville, Kentucky, 40292. Submissions should follow the guidelines of the PUBLICATIONS MANUAL of the American Psychological Association (1974, rev) and/or A MANUAL OF STYLE, University of Chicago Press (12th ed.). However, the editors recognize and accept the MLA format.

RATES. North America $\$ 10$; all other countries $\$ 15$; students $\$ 5$. Sustaining members $\$ 100$. Institutional subscription $\$ 15$. Back issues are $\$ 5$ each.

Dues, subscriptions, changes of address, and orders for back issues should be sent to: Academic Publications, University of Louisville, Louisville, Ky, 40292, U.S.A. Payment is required in U.S. funds drawn on U.S. or Canadian banks. Make all checks payable to NALLD.

Advertising queries should be sent to Dr. Les Bailey, Advertising Manager, NALLD JOURNAL: TECHNOLOGY AND MEDIATED INSTRUCTION, Room 48B, Kresge Centennial Hall, Northwestern University, 1859 Sheridan Road, Evanston, Illinois, 60201, U.S.A.

POSTMASTER: Send Form 3579 to NALLD, Academic Publications, University of Louisville, 2301, South Third Street, Louisville, Ky, 40292, U.S.A.

Third class postage paid at Louisville, Kentucky.

Copyright 1980 by the National Association of Learning Laboratory Directors. 
NALLD

Journal

of

Technology

and

Mediated Instruction

President

Joseph H. Sheehan

University of

Houston

Vice President

Victor Aulestia

University of

Maryland-Baltimore

County

Executive Sec'y

Samuel Burggraaf

Brigham Young

University

Treasurer

Leslie Bailey

Northwestern

University

Recording Sec'y

Jackie Tanner

University of

Virginia

Journal Editor

Dale V. Lally Jr.

University of

Louisville

\section{CONTENTS}

The Roles of U-Matic vs. VHS- Consideration

for Educational Technologists

Steve Kanaba

A Study of the Effect of "Slowed Speech" on Listening Comprehension of French

Philip D. Smith, Jr.

OFF THE AIR

Edmun B. Richmond

NALLD Journal Index 1968-1979

$$
\text { Jackie Tanner }
$$

TOPICAL INDEX

Lab Facilities Described

45

Video, Media, Systems

46

Pennsylvania Study, Survey, Language

Laboratory

Recommendations for Labs

Audio

Conference Update

Dale V. Lally Jr.

50

1978 Membership Directory

52

REVIEWS

Stephen Spangehl

65

NALLD News

67

NALLD Note from the Editor

69 
NALLD JOURNAL:

Technology and Mediated Instruction

Journal of the National Association of Language Laboratory Directors

Volume 14 , Numbers $3 / 4$

Issue: Spring/Summer 1980

Editor-in-Chief Dale V. Lally Jr, University of Louisville

Co-Editor

Denzil Edge, University of Louisville

Co-Editor

James Eiseman, University of Louisville

Co-Editor

Robert N. St. Clair, University of Louisville

Associate Editors

Charles P. Richardson, Ohio University

Flint Smith, Purdue University

Advertising Mapager Leslie Bailey, Northwestern University

DEPARTMENTS

Off-the-Air

Reviews

Edmun Richmond, Georgia Institute of Technology

Conference Updates

NALLD News Steven Spangehl, University of Louisville

Dale V. Lally Ir, University of Louisville

Editors

INTERNATIONAL EDITORIAL CONSULTANTS

Liliana Baltra

Centro de Perfeccionamiento,

Experimentacion e investigaciones

Pedagogicas (CPEIP)

Casilla 16162

Santiago 9, Chile

Yakov Borisovich Krupatkin

u.l. Odesskaja 1, kv. 19

Sevastopol 335000, USSR
Takashi Kuroda

Language Laboratory Association of Japan

English Literature Department Otsuma Womens College 12, 3- Bancho, Chiyoda-ku Tokyo, 102, Japan

Reinhold Freudenstein Foreign Language Research Information Center Lahnberge

D-3550 Marburg/Lahn Federal Republic of Cermany 